\title{
1. Introduction to urban food security in the Global South
}

\author{
Jonathan Crush, Bruce Frayne and Gareth \\ Haysom
}

Food and cities are so fundamental to our everyday lives that they are almost too big to see. Yet if you put them together, a remarkable relationship emerges. (Steel, 2008, p. ix)

\section{INTRODUCTION}

This book sits at the confluence of three transformative processes in the Global South. First, the South is undergoing a rapid urban transition fuelled by natural population increase and migration. Attendant to this urban transition are many daunting challenges, not the least of which is how hungry cities and city regions will actually be fed. Second, the cities of the South have witnessed major changes in the ways in which their food supply is organized. In the vanguard of this second transformation are new linkages to global processing and distribution networks, that are vertically integrating all aspects of the food value chain and incorporating cities into global food markets. Third, there is a major upsurge in levels and trends of food insecurity in the cities of the South. Long a characteristic of rural populations, undernutrition and overnutrition are both rising in the cities and towns of the Global South, and constant hunger is the lot of millions. Yet, most cities are not short of food; the key issue is not how to grow more but how to improve access to the food that is available.

The central proposition of this book is that the links between these three processes are imperfectly understood, partly because they have been sidelined by the anti-urban bias of the new international food security agenda (Crush and Frayne, 2011; Crush and Riley, 2018). If a fraction of the resources devoted to developing new agricultural technologies were directed to applied research and policy-making on urban food insecurity, the countries and cities of the Global South would be in a much better position to comprehend and respond to the growing crisis. Most new urbanites are not going to grow all their own food, nor are they going to be fed by the household members they left behind in the rural areas, places they left precisely so that they could locate an income and improve the food security and life chances of all. Failure to address the 
development challenges of urban food insecurity, rising food prices, and low incomes will have serious unintended consequences for the Global South and will undermine efforts to achieve a sustainable urban future.

This book's aim is to unpack the various dimensions of food and nutrition insecurity that is now a pervasive characteristic of cities and towns in the Global South. Each chapter investigates and explains key dimensions of the rising urban food and nutrition security challenge, and also provides insights as to possible pro-poor policy and investment pathways that can properly address this key developmental imperative in our predominantly urban world. The remainder of this chapter provides the context of the urban food challenge facing the Global South, which is followed by an outline of the subsequent chapters and their contributions to this critical development challenge confronting the global community in the 21st century.

\section{THE SECOND URBAN TRANSITION}

Saunders (2010, p. 1) begins his exploration of global urbanization with the prediction that "what will be remembered about the 21st century, more than anything else except perhaps the effects of a changing climate, is the great, and final, shift of human populations out of rural, agricultural life and into cities." The international community has only recently accepted that the fundamental urban transition taking place across the Global South is not a temporary or reversible phenomenon (Seto, et al., 2017). In contrast to the first urban transition in the Global North, the process is taking place much more rapidly and involves much larger numbers of people. Urbanization in the Global South outstrips the growth of 19th-century cities in Europe and North America, with the result that in 2020, more countries have moved from incipient and moderate to extensive and advanced urbanization (Smith, 2019). Fuelled by the second transition, the world's urban population is expected to continue to rise to nearly 60 per cent by 2025 and to two-thirds by mid-century. In contrast, the rural population is expected to stabilize in 2020 and then to start declining (Figure 1.1). The combined urban population of Africa, Asia and Latin America increased from 1.8 billion in 1995 to 2.9 billion in 2015 and is projected to rise to 3.7 billion by 2050. In 1950, only 24 per cent of countries (mainly in Europe and North America) were more than 50 per cent urbanized. By 2014, this figure had increased to 63 per cent and is projected to exceed 80 per cent by 2050 (UN, 2015, p. 7).

Current levels of urbanization vary considerably but all regions are becoming more urbanized (Figure 1.2). In the Global South, Latin America urbanized the earliest and now has levels of urbanization comparable to those in Europe and North America. Asia is currently urbanizing at the fastest rate, with countries such as China and India at the forefront. Even in Africa, often regarded 


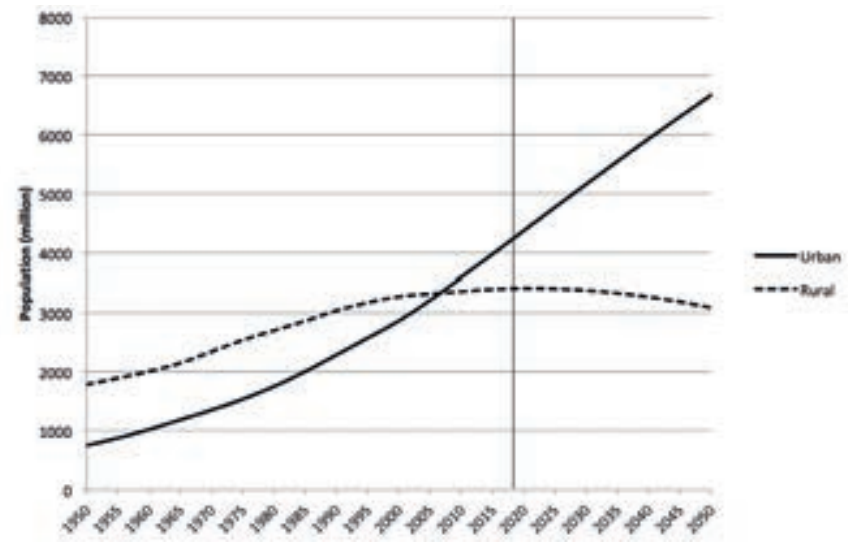

Source: UN, 2015, p. 7.

Figure 1.1 Global urban and rural population
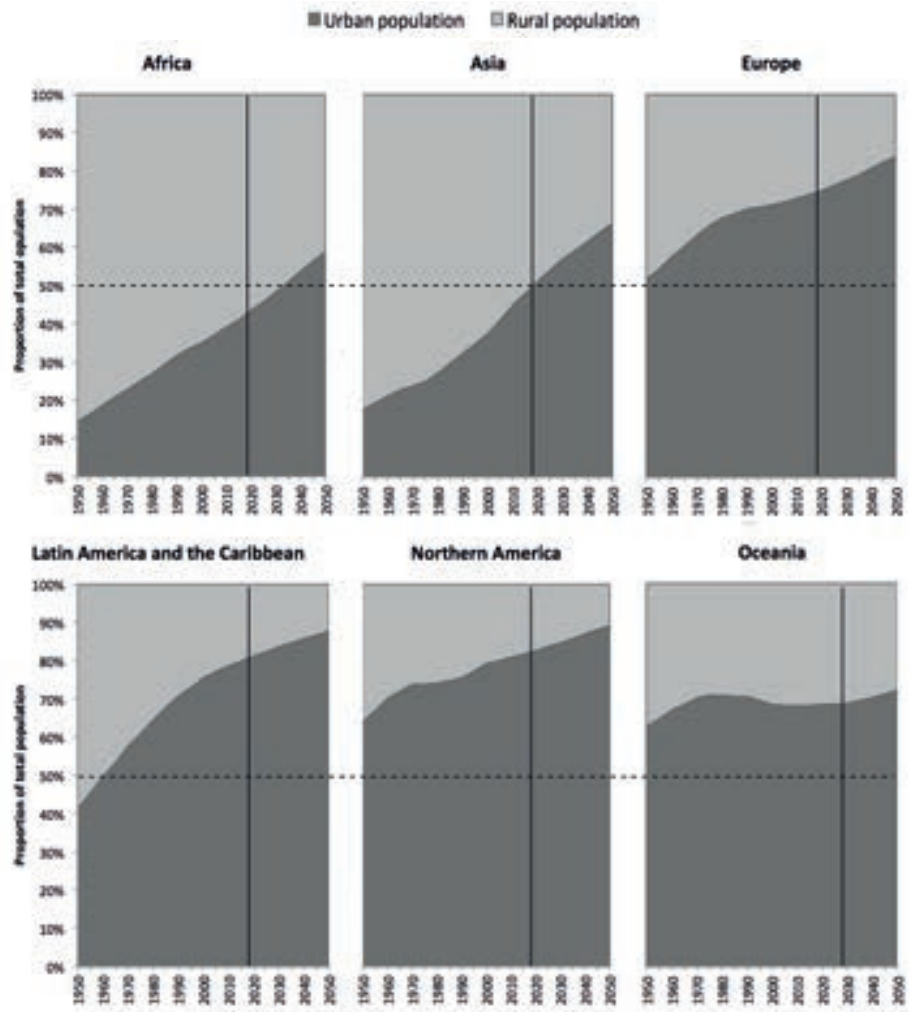

Source: UN, 2015, p. 10.

Figure 1.2 Level of urbanization by region, 1950-2050 


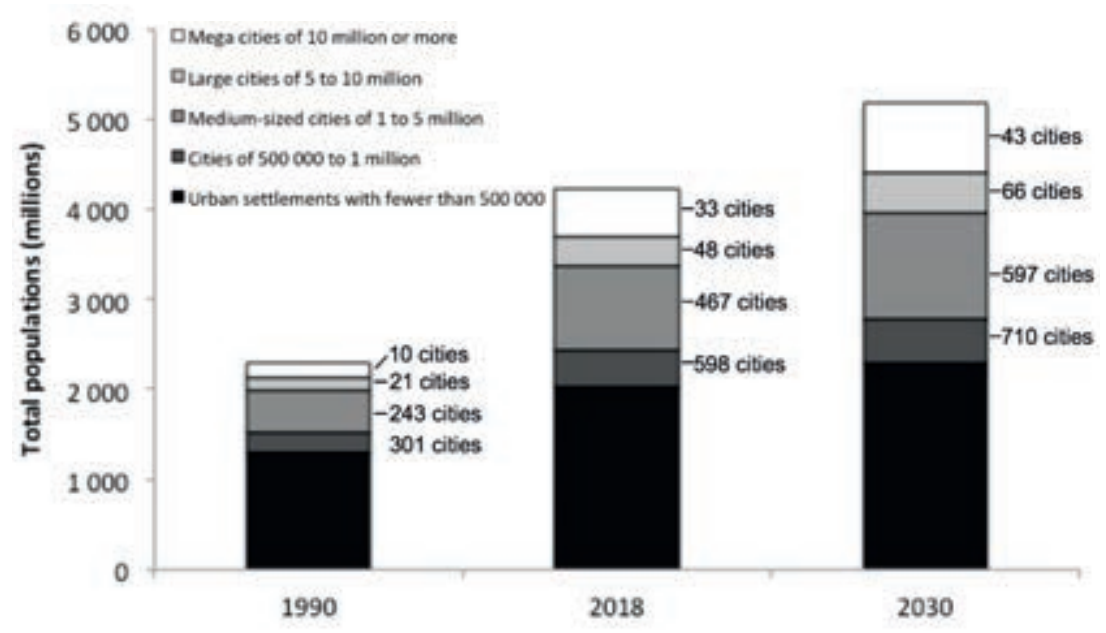

Source: UN, 2019, p. 58.

Figure 1.3 Urbanization trends and city size, 1990-2030

as the most rural region of the Global South, the urban transition is well under way. The urban population of Africa increased from 248 million (or 34 per cent) in 1995 to 412 million (44 per cent) in 2010 and is projected to climb to 658 million (47 per cent) by 2025. By 2030, there will be more people living in towns and cities in Africa than in the countryside.

By 2050, the bulk of the world's urban population will be living in the Global South and especially Asia (52 per cent) and Africa (21 per cent). The number of megacities (of over 10 million in size) increased from 3 in 1950 to 29 in 2015 and is projected to rise to 43 in 2030 (UN, 2018). The majority of megacities and large cities of 5 to 10 million inhabitants are in the Global South. However, the fastest growth is in the number of secondary cities (Figure 1.3). The number of cities with 1 to 5 million people increased from 127 in 1970 to 439 in 2015 and those with populations of 300,000 to 1 million, from 415 in 1970 to 1261 in 2015 (UN, 2019).

The UN estimate is instructive in detailing the importance of secondary cities in the transition and in global urbanization more generally (Battersby and Watson, 2019). The data demonstrates that in 2015, the number of urban Africans residing in cities of one million or less totalled slightly less than 320 million. Those residing in cities of more than one million made up 175 million (UN, 2019). According to Chai and Seto (2019), urban areas of less than 500,000 are now home to just over a quarter of the world's population. 
The rate of urbanization in Latin America over the last 50 years has been called "remarkable" (Cerrutti and Bertoncello, 2006, p. 140). Within the region, however, the pace of urbanization has varied from country to country. These authors suggest that there are four groups of country based on their level of urbanization: incipient (40-50 per cent urban), moderate (55-65 per cent urban), extensive (70-80 per cent urban) and advanced (85-95 per cent urban). The drivers of Latin America's urban transition have been analyzed in considerable detail, but it is clear that rural poverty and fundamental transformation of the agricultural sector from peasant production to large-scale commercial farming have been critical drivers (Portes and Roberts, 2005; Roberts, 2005; Rodgers et al., 2011; Thurlow et al., 2019).

If Latin America's urban transition is remarkable, Asia's is "profound" (Hugo, 2006, p. 115). Almost half of all the world's urban residents now live in Asia. By 2030, Eastern Asia (including China, South Korea and Japan) is projected to be 63 per cent urban, South-Eastern Asia (including Indonesia, Malaysia, Thailand, Vietnam and the Philippines) to be 56 per cent urban, and South-Central Asia to be 44 per cent urban. Among the most urbanized Asian countries will be South Korea (90 per cent), Japan (85 per cent), Indonesia (64 per cent) and China (60 per cent). One of the defining characteristics of Asian urbanization has been the emergence of megacities (defined as urban agglomerations of over 10 million people) (Hugo, 2006, p. 119). In 2001, two-thirds of the world's megacities were in Asia (Tokyo, Mumbai, Calcutta, Dhaka, Delhi, Shanghai, Jakarta, Osaka, Beijing, Karachi and Manila). Latin America had three (Sao Paulo, Rio de Janeiro and Buenos Aires), and North America just two (Mexico City and New York).

Africa as a whole is at an earlier stage of the transition, although countries such as South Africa and Botswana are already more than 60 per cent urban. The least urbanized African region is Southern Africa which will still be only 35 per cent urbanized in 2030. However, it does have the highest rates of urbanization in the world (UNDESA, 2018). The most urbanized region is Eastern Africa, which became more than 50 per cent urban between 1990 and 2000. By 2030, the proportion of people living in towns and cities could exceed 60 per cent. In Northern Africa, levels of urbanization were 47 per cent in 2010 and are projected to increase to 58 per cent by 2030. Some Northern African countries (such as Algeria and Libya) already have levels of urbanization equivalent to North America and Europe. The urban population of Western Africa was projected to pass 50 per cent between 2010 and 2020 and rise to 56 per cent by 2030.

While some have questioned the UN methodology for projecting future urbanization levels, no one seriously contends that the transition towards a predominantly urban future in the Global South is a statistical invention. Promoters of rural development in Africa (such as the Alliance for a Green Revolution 
in Africa, the UN Food and Agriculture Organization, and the International Fund for Agricultural Development) suggest that urbanization is an inherently negative and problematic phenomenon that can and should be slowed, or even reversed, through judicious technocratic support of rural small farmers. IFAD's president recently argued, for example, that "if smallholders are excluded from the region's food security response, they will follow a well-trodden path to over-crowded urban areas and abroad. Rural areas will become increasingly depopulated ... Africa needs vibrant rural areas that offer a variety of enterprises of all sizes, providing employment, income and food security, as well as offering essential environmental services" (IFAD, 2013). Romantic visions of pastoral Africa may provide a convenient rationale for institutional relevance but fly in the face of reality. As Collier (2009, p. 62) notes, "peasant agriculture offers only a narrow range of economic activities with little scope for sustaining decent livelihoods. In other societies people have escaped poverty by moving out of agriculture. The same is true in Africa: young people want to leave the land; educated people want to work in the cities. Above all, people want jobs". As Gebre-Egziabher (2019, p. 219) observes, "the welfare gains of properly managed urbanization for urban dwellers come in the form of higher income and employment, better access to services and infrastructure" (see also Collier and Dercon, 2014).

In the context of the second urban transition, it is now increasingly recognized that the cities of the South are confronting a deepening crisis of food inaccessibility, characterized by growing food poverty, hunger and malnutrition, a lack of dietary diversity, child wasting and stunting, increased vulnerability to infectious and chronic disease, and a growing obesity epidemic (Caprotti et al., 2017; Crush et al., 2012; Frayne and McCordic, 2018; MSSRF and WFP, 2010; Popkin et al. 2012; Popkin, 2017). However, this urban crisis still seems largely invisible to the policy and research communities concerned with global food security.

\section{THE SOUTHERN URBAN FOOD CRISIS}

In 1996, the Rome World Food Summit Plan of Action offered a new definition of food security which has since become embedded in academic and policy discourse: "Food security exists when all people, at all times, have physical and economic access to sufficient, safe and nutritious food to meet their dietary needs and food preferences for an active and healthy life" (FAO, 1996, Article 1). The staying power of this definition is due to the fact that it moves beyond the unsustainable idea that food insecurity is simply a matter of insufficient food production. In the urban context, in particular, where households have to purchase most of their food and other goods and services, food security 


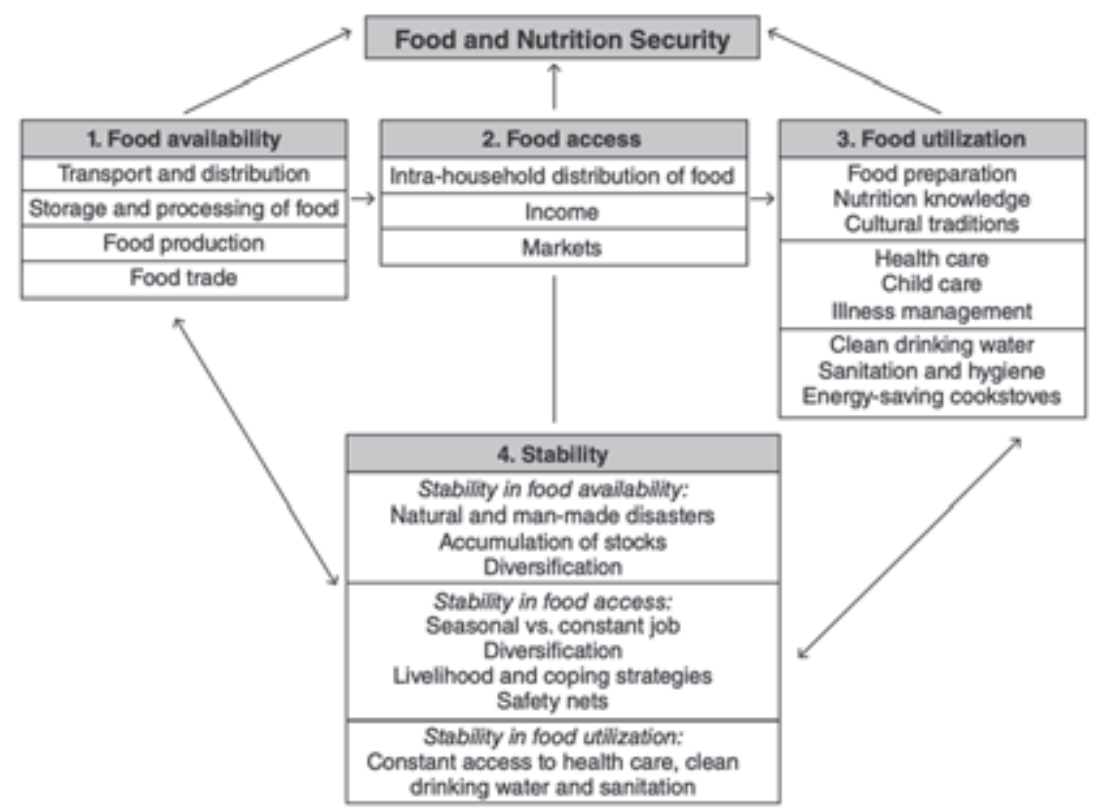

Source: Burchi et al., 2011.

Figure 1.4 The four dimensions of food security

"depends to a large extent on individual household circumstances as the household operates within this purchasing environment” (Teng and Escaler, 2010, p. 2). The FAO definition suggests that a holistic understanding of food security should focus on four interlinked issues: food availability, food access, food utilization and food stability (Burchi et al., 2011) (Figure 1.4).

Understanding these different dimensions of food security and their interrelationship is clearly a trans-disciplinary challenge (Drimie and McLachlan, 2013). For example, the food utilization component in Figure 1.4 identifies "food preparation, nutrition knowledge and cultural traditions" as determinants of food insecurity. Thus, people may be consuming a sufficient number of calories but if the food is unsafe, their dietary diversity is poor, and they are forced to eat food they prefer not to, then, by this definition, they are food insecure. To fully comprehend these connections would require an approach that incorporated concepts and methodologies from the social sciences and humanities as well as nutrition and public health.

The measurement of food security in the urban context is a subject of considerable debate (Haysom and Tawodzera, 2018). Anthropometric measures of food insecurity outcomes are widely used in the biomedical literature. The 
Table 1.1 Prevalence of undernutrition in children (age 6-36 months) in urban India, 2005-2006

\begin{tabular}{llll}
\hline State & \% Stunted & \% Wasted & \% Underweight \\
\hline Andhra Pradesh & 33 & 15 & 24 \\
Assam & 35 & 19 & 28 \\
Bihar & 38 & 37 & 33 \\
Gujarat & 42 & 17 & 36 \\
Haryana & 36 & 24 & 37 \\
Karmataka & 34 & 17 & 26 \\
Kerala & 27 & 9 & 15 \\
Madhya Pradesh & 41 & 31 & 44 \\
Maharashtra & 40 & 15 & 27 \\
Orissa & 36 & 14 & 28 \\
Punjab & 33 & 11 & 20 \\
Rajasthan & 29 & 20 & 26 \\
Tamil Naidu & 30 & 22 & 23 \\
Uttar Pradesh & 33 & 13 & 26 \\
West Bengal & 30 & 13 & 24 \\
Total & 37 & 19 & 30 \\
\hline
\end{tabular}

Source: MSSRF and WFP, 2010, pp. 72-5.

three most common are child wasting (low weight for height), stunting (low height for age) and underweight (low weight for age). A national study of urban food security in India reported, for example, that in all but one Indian state, more than a third of children in urban areas were stunted (Table 1.1) (MSSRF and WFP, 2010). Levels of wasting varied from a low of 9 per cent in Kerala to a high of 37 per cent in Bihar. In almost every state, over 20 per cent of children were underweight. Apart from the very high levels of child undernutrition captured in these figures, there are striking differences from state to state and, by extension, city to city.

Another conventional measure of food insecurity is the amount of dietary energy consumed by individuals or a household. Various cut-offs are generally used to classify the undernourished into increasingly deprived groups: for example, the subjacent hungry (1800-2200 kcals per person per day); the medial hungry (1600-1800 kcals per person per day) and the ultra-hungry (less than 1600 kcals per person per day) (Ahmed et al., 2011). In a number of countries food-energy deficiencies are already higher in urban than rural areas (Ahmed et al., 2011, p. 38). The Global Hunger Index (GHI) combines food-energy with anthropomorphic data including the proportion of people who are food-energy deficient, the prevalence of underweight children under five, and the under-five child mortality rate (IFPRI, 2012). The GHI is a useful composite measure for tracking changes over time but tends to rely primarily on national level data. 
As a result, its utility for tracking and mapping levels of urban food insecurity is untested.

Experiential efforts to measure the utilization dimension of food insecurity include the World Food Program's Food Consumption Score (FCS) and the Hungry Cities Food Purchases Matrix (HCFPM), which have been usefully applied in case studies in Accra, Ghana and Maputo, Mozambique at the subnational urban scale to link food insecurity with dietary diversity, food consumption frequency, and food sourcing behaviour (Crush and McCordic, 2017; Tuholske et al., 2020; Wiesmann et al., 2009). More widely used at the subnational level are a set of cross-cultural measures of food access insecurity developed by the FANTA (Food and Nutrition Technical Assistance) Project in Washington DC (Swindale and Bilinsky, 2006). The FANTA methodology was used in a baseline survey of poor households in 11 cities in Southern Africa by the African Food Security Urban Network (AFSUN) (Crush et al., 2012; Crush and Battersby, 2016; Frayne et al., 2018). The survey revealed a stark picture of food insecurity in poor urban neighbourhoods across the region. Only 17 per cent of the 6453 poor households surveyed were classified as food secure on the FANTA scale (Figure 1.5). As many as 57 per cent were severely food insecure and another 19 per cent were moderately food insecure. In cities in crisis, such as Harare (Zimbabwe) and Manzini (Swaziland), food security rates were less than 7 per cent and severe food insecurity levels were over 70 per cent. Other findings included consistently low dietary diversity, severe fluctuations

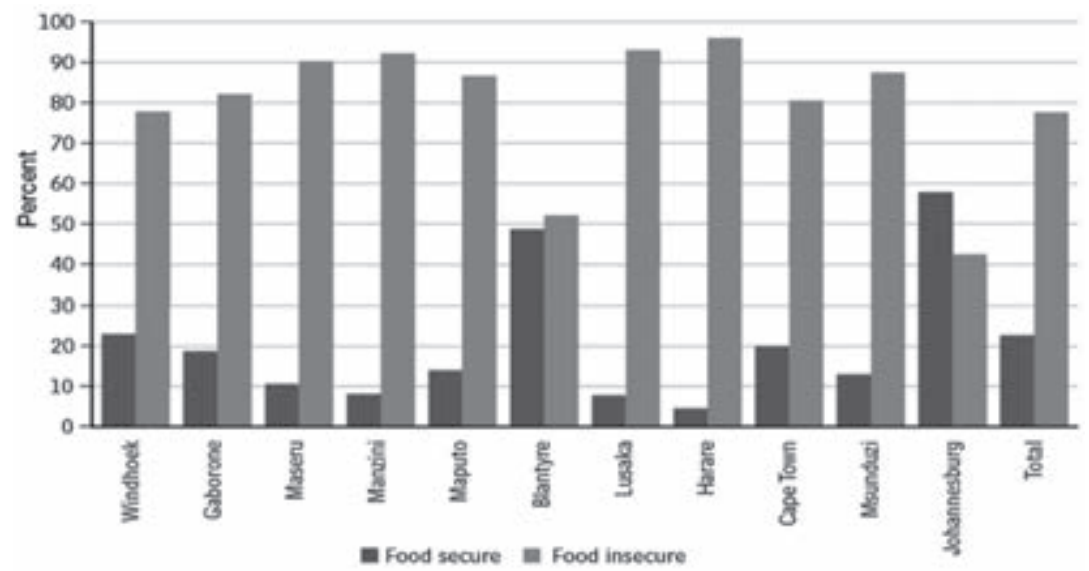

Source: Crush et al., 2012.

Figure 1.5 Levels of food insecurity in Southern African cities 
in levels of food insecurity during the year, and particular vulnerability to food insecurity on the part of female-headed households.

Popkin and Gordon-Larsen (2004, p. S2) observe that "there has been increasing evidence that the structure of dietary intakes and the prevalence of obesity around the developing world have been changing at an increasingly rapid pace”. Urban food insecurity is therefore increasingly viewed as a problem of both undernutrition (insufficient good quality food) and overnutrition (too much of the wrong kinds of food) (Popkin et al., 2012). A review of 28 studies in West Africa, for example, found that the prevalence of urban obesity had doubled in the previous decade and a half (Akubakari et al., 2008). Another study of West African cities reported that the prevalence of obesity increased by nearly 35 per cent between 1992 and 2005 (Ziraba et al., 2009). Amugsi et al. (2017) found that rates of overweigh and obesity among urban women had increased between 1991 and 2014 in all 24 African countries studied, with rates doubling or tripling in half of them. In Latin America, a recent study of seven major cities found that 23.5 per cent of the adult population was obese (Armaz-Hernandez et al., 2016). In addition, "childhood obesity is on the rise as a result of diets that favour energy-dense, nutrient-poor foods and the adoption of a sedentary lifestyle” (Corvalán et al., 2017, p. 7). The Asian Development Bank has warned of an imminent "obesity crisis" in Asia and the Pacific where over 40 per cent of the adult population is already overweight (Helble and Francisco, 2017).

In the Global South, obesity rates tend to be significantly higher amongst females than males and amongst urban than rural populations as high-fat, highsugar urban diets displace more traditional fare (Ford et al., 2017; Harris et al., 2019; Ruel et al., 2017; Subramanian and Davey Smith, 2006). Obesity is also increasingly affecting the urban poor (Case and Menendez, 2009; Frayne et al., 2014; Monteiro et al., 2007). Studies in India show that poor migrants who move from the countryside to the city immediately begin to experience higher rates of obesity and chronic disease as a result of changes in diet (Ebrahim et al., 2010). In many households in poor urban communities in the South there is also evidence of a "nutrition transition paradox" of child undernutrition and adult obesity within the same household (Dang and Meenakshi, 2017; Doak et al., 2005; Roemling and Qaim, 2013; Van Hook et al., 2013). As Caballero (2005, p. 1515) notes “cheap, energy-dense, nutrient-poor foods may adversely affect the growth of the child but may provide sufficient calories for the adult to gain excess weight”. The growing public health and economic burden of soaring rates of urban obesity has been documented most thoroughly in countries such as Mexico (Levasseur, 2019; Rtveladze et al., 2013).

Changes in levels and types of food insecurity accompanying the urban transition in the Global South are increasingly well-documented. Coherent strategies to mitigate rising levels of undernutrition and overnutrition are, by 
contrast, virtually non-existent. Very few national and city governments have thought systematically about the challenges or developed food and nutrition security plans for their burgeoning urban populations (Haysom, 2015). One of the many complex policy challenges is the dramatic transformation in urban food systems over the last three decades. This involves "extensive consolidation, very rapid institutional and organizational change, and progressive modernization of the procurement system” (Reardon and Timmer, 2012, p. 225).

As the urban transition in the Global South continues to gain momentum, food and nutrition insecurity has become a serious, multi-faceted and neglected development challenge in its cities and towns. The next section examines the nature of the international community's response to this challenge since one of the aims of this volume is to raise global awareness of the different dimensions of the crisis of urban food security.

\section{SUSTAINABLE DEVELOPMENT AND URBAN FOOD SECURITY}

In the last five years, two key global compacts have been ratified, which place cities at the centre of the sustainable development imperative: The New Urban Agenda (UN, 2017) and the United Nations 2030 Agenda for Sustainable Development (UN, 2018). Embedded in both of these global development strategies is the recognition that building sustainable and food secure cities is one of the critical development issues of the 21st century (Barling and Fanzo, 2018; Birch and Wachter, 2011; Blay-Palmer, 2016; Fox, 2011; Haysom et al., 2019; Satterthwaite et al., 2010).

In 2015, the UN General Assembly decided to convene the Habitat III Conference "to reinvigorate the global commitment to sustainable urbanization, to focus on the implementation of a New Urban Agenda, building on the Habitat Agenda of Istanbul in 1996” (UN, 2017). The New Urban Agenda (NUA) was adopted at the United Nations Conference on Housing and Sustainable Urban Development (Habitat III) in Quito, Ecuador, on 20 October 2016, and was endorsed by the United Nations General Assembly at its sixty-eighth plenary meeting of the seventy-first session on 23 December 2016 (UN, 2017). The main objectives included the securing of "renewed political commitment for sustainable urban development, assess accomplishments to date, address poverty, and identify and address new and emerging challenges” (UN, 2017). The NUA highlights food security as a key element of a sustainable urban future, as Article 5 shows:

By readdressing the way cities and human settlements are planned, designed, financed, developed, governed and managed, the New Urban Agenda will help 
to end poverty and hunger in all its forms and dimensions; reduce inequalities; promote sustained, inclusive and sustainable economic growth; achieve gender equality and the empowerment of all women and girls in order to fully harness their vital contribution to sustainable development; improve human health and wellbeing; foster resilience; and protect the environment.

The HABITAT III conference took place shortly after the adoption of the 2030 Agenda for Sustainable Development and the Sustainable Development Goals (SDGs) and provides a potentially important corrective (UN, 2017). The SDG commitment to ending poverty and hunger in all its forms is directly addressed in Goals 1 (end poverty) and 2 (zero hunger). This congruency is important and provides the mandate for the global community to address food and nutrition security head-on within the context of the drive towards a more sustainable urban future. However, while the New Urban Agenda does well to highlight food and nutrition security as a key element of the urban sustainable development priorities, cities and food are in fact not integrated within the SDG framework, a problem which also characterized the earlier Millennium Development Goals (Battersby, 2017; Battersby and Watson, 2018a).

The inclusion of an urban Sustainable Development Goal (SDG 11) represents an important acknowledgement of the reality of global urbanization and the many social, economic, infrastructural and political challenges posed by the human transition to a predominantly urban world (Sgro et al., 2019). However, while SDG 11 (Sustainable Cities and Communities), provides goals for housing, transportation, land use, cultural heritage and disaster risk prevention, food is not mentioned at all. Similarly, SDG 2 Zero Hunger, focuses on food production and marketing, but makes no reference to urban residents' access to that food. This conundrum reflects the dichotomy in thinking and programming when it comes to food and cities. As already highlighted, access to food remains the key development challenge for impoverished urbanites, and not food supply or availability.

This siloed approach to food security is only the latest example of a more chronic problem. With few exceptions, food insecurity in the Global South has been sidelined in urban research and policy-making over the last decade (Battersby and Watson, 2018b; Crush and Frayne, 2011; Crush and Riley, 2018; Frayne et al., 2018). When the UNDP (2012) called for "inclusive growth and people-centred approaches to food security”, for example, it framed the issue purely as a matter of rural production and employment (Hanson, 2013; Spoor and Robbins, 2012). When the current operationalization and reporting on the SDG agenda is considered, a further concern emerges. There is a real risk that the framing of hunger in SDG 2 as a production challenge will divert attention to rural hunger. If the adage that "what is measured is managed" is applied, the SDGs and their resultant reporting could unintentionally further marginalize 
urban food security and so deepen hunger and malnutrition in the towns and cities of the Global South.

When the UNDP (2012) called for "inclusive growth and people-centred approaches to food security", it framed the issue purely as a matter of rural production and employment (Hanson, 2013; Spoor and Robbins, 2012). Indeed, there was more research and policy debate on urban food insecurity in the 1990s, when the South was a lot less urbanized than it is today (Drakakis-Smith, 1991; Maxwell, 1999; Smith, 1998). The only aspect of urban food security that continues to command significant attention has been urban agriculture, which is widely but improbably seen as the key to cities feeding themselves (Badami and Ramankutty, 2015; Binns and Nel, 2020; Crush et al., 2011; Frayne et al., 2014; Lee-Smith, 2010).

\section{CONTRIBUTIONS}

A number of themes run through the chapters of this edited volume. Six are highlighted here: scale and context; markets; governance; transitions; interconnectedness; and networks. As readers will observe, many of the chapters speak to more than one theme, while a number of chapters appear to take contradictory positions on key issues. This is a deliberate editorial strategy and the result of authors being asked to write to their own specific disciplines, viewpoints and areas of research. These tensions demonstrate the emerging and disputed nature of urban food system theorization and normative positioning in the Global South. To curate uniformity in positions and perspectives would have meant excising many important and critical voices within this contested domain.

\subsection{Scale and Context}

The first theme pertains to questions of appropriate conceptual and methodological scale and context for addressing urban food security, and whether and how to link the global and the local. All of the contributors were asked to "think global" and produce overviews and syntheses that relate to more than one region of the world. As we have argued above, and the chapters by Cecilia Tacoli, James Tefft and Marketa Jonasova, and Tony Weis et al. confirm, the industrialization and globalization of food production, distribution and access provides essential context for understanding the general drivers of rapid urbanization and urban food security. That said, it is clear that food security challenges, outcomes and responses vary considerably from region to region, country to country, and city to city. The chapters in this volume take two approaches to the analysis of spatial variation: some, such as those by Reena das Nair, Jonathan 
Crush and Mary Caesar, and Daniel Warshawsky test global generalizations about the supermarket revolution, food remittances and food banking against case study evidence from Southern Africa. Others, such as those by Susan Horton, Piero Conforti et al., Carrie Mitchell et al. and Abel Chikanda et al., adopt a comparative approach to issues such as overnutrition, urban agriculture, climate change and migration to demonstrate the existence of considerable inter-country and inter-city heterogeneity.

One of the most important scalar questions addressed here has arisen in response to the city-region approach advocated by the UN FAO, the Milan Urban Food Pact and the New Urban Agenda. Here there are clear tensions over the the role and importance of city regions and localism. The chapters by Tefft and Jonasova, and Felicity Proctor and Julio Berdegué suggest clear advantages in a City Region Food System (CRFS) approach. Others, such as Conforti et al. and Marie Ruel et al. foreground the importance of local production, specifically in peri-urban areas. However, other chapters, such as those by Jane Battersby and Vanessa Watson, and Gareth Haysom, historicize and explicitly challenge the universal applicability of the City Region approach. Tacoli, Liam Riley and Belinda Dodson, and Jodi Koberinski et al. are less direct in their challenge but caution against a production-dominated focus in urban food security responses. These tensions demonstrate the divergent positions in emerging scholarship in the field of urban food systems research. While there may be a measure of emerging consensus on issues pertaining to urban food system studies in the Global North, this is not as evident in the Global South and this book deliberately seeks out some of these contradictions.

\subsection{Markets}

Reflecting the 1996 FAO definition of food security, this book explicitly focuses on the accessibility, utilization and stability dimensions of food and nutrition security. As a result, there is a clear focus on the role of the market, in all its forms. This includes supermarkets and the emerging "middle" in the works of Thomas Reardon on the quiet revolution in the midstream of agrifood value chains, and das Nair, who offers nuance to discussions of the supermarket "revolution" in the South. An additional area of focus is that of the informal food retailing economy whose importance to poor urban households as a source of income and food is increasingly recognized by researchers, and repudiated by national and local policy-makers. Here the contributions by Tacoli, Graeme Young and Jonathan Crush, and Ruel et al. offer important insights into the needs and challenges faced by the economy and how different conceptualizations of informality lead to very different policy and regulatory responses. These chapters also underscore the central role that urban governance plays 
in urban food systems, even if indirectly through non-food-related governance actions imposed on food system actors.

\subsection{Governance}

This book offers important new insights into urban food systems governance theorization in the Global South. Haysom, for example, argues that pluralistic "Northern" views and arguments about urban food governance are being uncritically inserted, or worse, imposed (and adopted) in cities and regions in the Global South. More problematic still, many cities in the South do nor recognize the importance of food system governance and lack the exemplars and resources to change this situation. SDG 11 provides little guidance or incentive to rectify this situation. Food banking has emerged as a significant policy "solution" to food system dysfunction but, argues Warshawsky, suffers from inappropriate placement in many parts of the Global South, and uncertain impacts on food insecurity and food waste levels over the long term. Tefft and Jonasova advocate an overall framework for urban food system governance in what they call TRANSFORM, which may command significant attention emerging, as it does, from World Bank thinking on the issues. Mitchell et al. examine the new era of governance hyper-experimentation and contend that it fails to address the important climate change-food security nexus and has the potential to exacerbate existing socio-economic inequality. A common thread in these chapters is the so-called absent urban mandate specific to food in cities of the South. By offering new insights into urban food governance questions and linking urban food system challenges to other urban governance mandates, they highlight the need for more Southern theorization that breaks with dominant Northern narratives of the city.

\subsection{Transitions}

The overarching purpose of this volume is to situate the current urban food security challenge within a series of inter-related transitions that will define the quality of human existence in the 21st century. These transitions pre-date the SDGs and will persist long after the 2030 Sustainable Development Agenda wraps up. Our concern is that the sidelining of the urban food security challenge, or its confinement within narrow production-oriented parameters, will inevitably mean that it does not receive the urgent research and policy attention it rightly should. Many of the chapters provide additional insights into the transitions identified at the outset of this chapter including rapid urbanization (Tacoli), the industrialization of the global food production and retail system (das Nair, Weiss et al.), climate change (Mitchell et al.), international mobility 
(Chikanda et al.) and the transformation of rural-urban linkages (Crush and Caesar, Proctor and Berdegué, and Reardon). Three chapters (by Horton, Tacoli, and Ruel et al.) demonstrate the scale of the nutrition transition, but also the significant rise in non-communicable diseases and the double burden of disease experienced in Southern cities. The chapter by Riley and Dodson further demonstrates how gender and power impact nutrition outcomes and how "what people eat in cities of the Global South is a reflection of their intersecting identities, as urban, gendered, classed, and belonging to contextually specific religious, regional, or ethnic groups”. All of these chapters on transition highlight the fact that the urban food question is far more than a question of production and that urgent attention is required to address the inter-generational consequences that the development deficit of poor nutrition brings.

\subsection{Interconnections}

A further theme that emerges in many of the contributions concerns linkages and connections and, in particular, the interconnected nature of the urban food challenge in cities of the South. Many chapters explicitly engage questions of the "nexus" or "interface” between food security and other processes. Mitchell et al. consider the climate change-food security nexus and the nature of experimentation taking place on this issue (together with some of the associated politics); Riley and Dodson focus on the "gender-urban-food" interface; and Koberinski et al. consider the food safety/food security nexus with specific reference to the impact of industrialization in Southern cities. Tefft and Jonasova position the urban food system at the heart of the food-water-energy nexus, while Chikanda et al. focus on the South-South migration and food security nexus, and Conforti et al. explore the urbanization-urban agriculture connection. Exploration of these interconnections demonstrates the nature and complexity of the urban food insecurity challenge and emphasizes the key point made in emerging Southern studies on urban food, namely that food and food insecurity intersects with a variety of other urban challenges and opportunities. A key contribution made by the chapters in this reader is that these intersections explicitly highlight the need for inter-, multi- and even trans-disciplinary research approaches. Additionally and importantly, food security questions in Southern cities raise critical governance and policy questions. Traditional Southern governance approaches, and often funding and development support, reinforce siloed governance systems and hierarchies. As a result, many Southern cities are stuck in outdated planning and governance regimes. This has a direct impact on urban food outcomes, something detailed throughout the volume. 


\subsection{Networks}

Many chapters either directly focus on networks and their roles in the food system, across multiple scales. Some chapters, such as those by Tefft and Jonasova, Weis et al., Proctor and Berdegué, and Crush and Caesar speak to networks that span the urban and rural scales and define the food-related and other flows between them. Mitchell et al., as well as Warshawsky, and Battersby and Watson, highlight the positive and negative roles that international networks play in defining priorities and interventions for addressing perceived urban challenges. While readers may note additional common themes, the six identified demonstrate the scope of the work detailed in this volume. The contributions highlight the regional and contextual differences in urban food security drivers, outcomes and associated challenges. Generalizations are not always productive and nuance is required - the Global South is not a uniform landscape. These differences and tensions within and between the chapters, serve to demonstrate the importance of context, the centrality of scale and, perhaps most importantly, the importance of using evidence derived from Southern contexts to formulate and engage Southern urban food system responses and theorization. While this statement may appear self-evident, the work contained in the following chapters demonstrates not only the different viewpoints, but also significant areas for new research consistent with the forward-looking agenda identified by Ruel et al.

\section{CONCLUSION}

Underlying the new international food security agenda are three propositions: first, the problem of food security is primarily one of inadequate national production and supply; second, the primary location of food insecurity is in the rural areas of the South; and, third, urbanization is an essentially problematic phenomenon which can be slowed and even halted by addressing the "root causes” of food insecurity (rural poverty and declining smallholder agriculture) (Crush and Frayne, 2011; Crush and Riley, 2018).

Despite the current donor and philanthropic enthusiasm for further "green revolutions" in the countryside, such efforts are highly unlikely either to stem the migration of people to the cities or to feed these newly urbanized populations. The Global South faces an increasingly urban future and food insecurity will become a primarily urban challenge (Chmielewska and Souza, 2011; Crush et al., 2012; Graziano da Silva and Fan, 2017; Frayne et al., 2018; Steel, 2009; Tacoli, 2019; Teng et al., 2011; Zingel et al., 2011). The knowledge gaps are many and a wide-ranging programme of research is urgently needed to uncover the dimensions and complexities of the phenomenon. Out of this will emerge 
policy responses that move beyond the pervasive idea that urban households can and will feed themselves or be fed by their impoverished elderly relatives on small plots in rural areas.

Notwithstanding the explicit identification of food and nutrition security within the NUA, and the SDG commitment to ending poverty and hunger, a key challenge that the global community currently faces is how to integrate these food-oriented development objectives in the urbanizing Global South. Meeting these objectives will certainly remain central endeavours in achieving a sustainable future, both within the 2030 Agenda timeline and beyond. This reader serves as a foundation, offering multiple entry points for new work on food systems and food security in Southern cities. Despite food and cities being fundamental to our everyday lives, we often do not see the connection, but when the issues are considered in a more collective manner, as here, a remarkable relationship emerges (Steel, 2009, p. ix).

\section{ACKNOWLEDGEMENTS}

This chapter includes material from Crush, Jonathan (2014). “Approaching food security in cities of the Global South.” In the Routledge Handbook on Cities of the Global South, edited by Susan Parnell, Sophie Oldfield, 45(543-55). Reproduced with permission of The Licensor through PLSclear, but has been revised and updated. We are particularly grateful to Mariella Salamone and Bronwen Dachs for their dedication and professionalism in bringing this volume to fruition. Funding for the preparation of this volume was provided by the Hungry Cities Partnership with an IPaSS grant from the Social Sciences and Humanities Research Council (SSHRC) and the International Development Research Centre (IDRC).

\section{REFERENCES}

Ahmed, A., R. Hill, S. Smith, D. Wiesmann and T. Frankenberger (2011), 'The world's most deprived: characteristics and causes of extreme poverty and hunger', 2020 Discussion Paper No. 22, Washington, DC, US: International Food Policy Research Institute.

Akubakari, A., W. Lauder, C. Agyemang, M. Jones, A. Kirk and R. Bhopal (2008), 'Prevalence and time trends in obesity among West African adult populations: a meta-analysis’, Obesity Review, 9, 297-311.

Amugsi, D., Z. Dimbuene, B. Mberu, S. Muthuri and A. Ezeh (2017), 'Prevalence and time trends in overweight and obesity among urban women: an analysis of demographic and health survey data from 24 African countries, 1991-2014', BMJ Open, 7, e017344.

Armas-Hernandez, M., R. Hernandez-Hernandez, H. Schardgrosky and H. Silva (2016), 'PS 09-12 obesity prevalence in urban population of Latin America', Journal of Hypertension, 34, e321.

Badami, M. and N. Ramankutty (2015), 'Urban agriculture and food security: a critique based on an assessment of urban land constraints’, Global Food Security, 4, 8-15. 
Barling, D. and J. Fanzo (eds) (2018), Advances in Food Security and Sustainability Volume 3, (1st Edition), London, UK: Academic Press.

Battersby, J. (2017), 'MDGs to SDGs - new goals, same gaps: the continued absence of urban food security in the post-2015 global development agenda', African Geographical Review, 36(1), 115-29.

Battersby, J. and V. Watson (eds) (2018a), Urban Food Systems Governance and Poverty in African Cities, London, UK: Routledge.

Battersby, J. and V. Watson (2018b), ‘Addressing food security in African cities', Nature Sustainability, 1(4), 153-5.

Binns, T. and E. Nel (2020), 'Reconceptualizing urban agriculture in Africa: issues of scale, class and institutional support in Zambian Copperbelt Towns', in A. Thornton (ed.), Urban Food Democracy and Governance in North and South, Cham, CH: Palgrave Macmillan, pp. 213-29.

Birch, E. and S. Wachter (2011), 'World urbanization: the critical issue of the 21st century', in E. Birch and S. Wachter (eds), Global Urbanization, Philadelphia, US: University of Pennsylvania Press, pp. 3-23.

Blay-Palmer, A. (ed.) (2016), Imagining Sustainable Food Systems, London, UK: Routledge, pp. 3-16.

Burchi, F., J. Fanzo and E. Frison (2011), 'The role of food and nutrition system approaches in tackling hidden hunger', International Journal of Environmental Research and Public Health, 8, 358-73.

Caballero, B. (2005), ‘A nutrition paradox: underweight and obesity in developing countries', New England Journal of Medicine, 352, 1514-16.

Caprotti, F., R. Cowley, A. Datta, V. Castán Broto, E. Gao, L. Georgeson, C. Herrick, N. Odendaal and S. Joss (2017), 'The New Urban Agenda: key opportunities and challenges for policy and practice', Urban Research \& Practice, 10(3), 367-78.

Case, A. and A. Menendez (2009), 'Sex differences in obesity rates in poor countries: evidence from South Africa', Economics and Human Biology, 7, 271-82.

Cerrutti, M. and R. Bertoncello (2006), 'Urbanization and internal migration patterns in Latin America', in E. Preston-Whyte, M. Tienda, S. Findley and S. Tollman (eds), Africa on the Move: African Migration and Urbanization in Comparative Perspective, Johannesburg, SA: Wits University Press.

Chai, B. and K. Seto (2019), 'Conceptualizing and characterizing micro-urbanization: a new perspective applied to Africa’, Landscape and Urban Planning, 190, 103595.

Chmielewska, D. and D. Souza (2011), The Food Security Policy Context in Brazil, Country Study No. 22, Brasilia, International Policy Centre for Inclusive Growth.

Collier, P. (2009), ‘Africa’s orgranic peasantry: beyond romanticism', Harvard International Review, 31, 62-3.

Collier, P. and S. Dercon (2014), 'African agriculture in 50 years: smallholders in a rapidly changing world?’, World Development, 63, 92-101.

Corvalán, C., M. Garmendia, J. Jones-Smith, C. Lutter, J. Miranda, L. Pedraza, B. Popkin, M. Ramirez-Zea, D. Salvo and A. Stein (2017), 'Nutrition status of children in Latin America 2017', Obesity Reviews, 18(S2), 7-18.

Crush, J. and B. Frayne (2011), 'Urban food insecurity and the new international food security agenda', Development Southern Africa, 28, 527-44.

Crush, J. and C. McCordic (2017), 'The hungry cities food purchases matrix: household food sourcing and food system interaction', Urban Forum, 28, 421-33.

Crush, J., A. Hovorka and D. Tevera (2011), 'Food security in Southern African cities: the place of urban agriculture', Progress in Development Studies, 11, 285-305.

Crush, J. and J. Battersby (eds) (2016), Rapid Urbanisation, Urban Food Deserts and Food Security in Africa, Dordrecht, NL: Springer.

Crush, J. and L. Riley, (2018), 'Rural bias and urban food security', in J. Battersby and V. Watson (eds), Urban Food System Governance and Poverty in African Cities, London, UK: Routledge, pp. 42-55.

Crush, J., B. Frayne and W. Pendleton (2012), 'The crisis of food insecurity in African cities', Journal of Hunger and Environmental Nutrition, 7, 271-92. 
Dang, A. and J. Meenakshi (2017), 'The nutrition transition and the intra-household double burden of malnutrition in India’, ADBI Working Paper 725, Asian Development Bank Institute, Tokyo.

Doak, C., L. Adair, M. Bentley, C. Monteiro and B. Popkin (2005), 'The dual burden household and the nutrition transition paradox', International Journal of Obesity, 29, 129-36.

Drakakis-Smith, D. (1991), 'Urban food distribution in Asia and Africa', Geographical Journal, 157(1), 51-61.

Drimie, S. and M. McLachlan, M. (2013), 'Food security in South Africa: towards a transdisciplinary approach’, Food Security, 5, 217-26.

Ebrahim, S., S. Kinra, L. Bowen, E. Andersen, Y. Ben-Shlomo, T. Lyngdoh, L. Ramakrishnan, R. Ahuja, P. Joshi, S. Mohan Das, M. Mohan, G. Davey Smith, D. Prabhakaran and K. Srinath Reddy (2010), 'The effect of rural-to-urban migration on obesity and diabetes in India: a crosssectional study', PLoS Medicine, 8(5), 10.

Food and Agriculture Organization of the United Nations (FAO) (1996), World Food Summit Plan of Action, Rome, 13-17 November, accessed 14 June 2018 at www.fao.org/docrep/003/ w3613e/w3613e00.HTM.

Ford, N., S. Patel and K. Narayan (2017), 'Obesity in low- and middle-income countries: burden, drivers, and emerging challenges', Annual Review of Public Health, 38, 145-64.

Fox, S. (2011), 'Understanding the origins and pace of Africa's urban transition', Crisis States Working Paper Series No. 89 (Series 2), London School of Economics and Political Science, London, UK.

Frayne, B. and C. McCordic (2018), 'Food swamps and poor dietary diversity: longwave development implications in Southern African cities’, Sustainability, 10(12), 4425.

Frayne, B., C. McCordic and H. Shilomboleni (2014a), 'Assessing contributions of urban agriculture to household food security in Southern African cities’, Urban Forum, 25(2), 177-98.

Frayne, B., J. Crush and M. McLachlan (2014b), 'Urbanization, nutrition and development in Southern African cities', Food Security, 6(1), 101-12.

Frayne, B., J. Crush and C. McCordic (eds) (2018), Food and Nutrition Security in Southern African Cities, London, UK: Routledge.

Gebre-Egziabher, T. (2019), 'Urbanization and linkages with rural economies in Ethiopia', in D. Rahmato and M. Ayenew (eds), Challenges and Opportunities for Inclusive Development in Ethiopia, Addis Ababa, ET: Forum for Social Studies.

Graziano da Silva, J. and S. Fan (2017), 'Smallholders and Urbanization: Strengthening Ruralurban Linkages to End Hunger and Malnutrition’, in 2017 Global Food Policy Report, Washington, DC, US: International Food Policy Research Institute (IFPRI), Chapter 2, pp. 14-23.

Hanson, C. (2013), 'Food security, inclusive growth, sustainability, and the post-2015 development agenda', Background Research Paper, High Level Panel on the Post-2015, Development Agenda, World Resources Institute.

Harris, J., B. Chisanga, S. Drimie and G. Kennedy (2019), 'Nutrition transition in Zambia: changing food supply, food prices, household consumption, diet and nutrition outcomes', Food Security, 11, 371-87.

Haysom, G. (2015), 'Food and the city: urban scale food system governance', Urban Forum, 26, 263-81.

Haysom, G. and G. Tawodzera, G. (2018), “"Measurement drives diagnosis and response”: gaps in transferring food security assessment to the urban scale', Food Policy, 74, 117-25.

Haysom, G., E. Olsson, M. Dymitrow, P. Opiyo, N. Taylor Buck, M. Oloko, C. Spring, K. Fermskog, K. Ingelhag, S. Kotze and S. Agong (2019), 'Food systems sustainability: an examination of different viewpoints on food system change', Sustainability, 11(12), 3337.

Helble, M. and K. Francisco (2017), 'The upcoming obesity crisis in Asia and the Pacific: first cost estimates’, ADBI Working Paper 743, Asian Development Bank Institute, Tokyo.

Hugo, G. (2006), 'Urbanization in Asia: an overview', in E. Preston-Whyte, M. Tienda, S. Findley and S. Tollman (eds), Africa on the Move: African Migration and Urbanization in Comparative Perspective, Johannesburg, SA: Wits University Press, pp. 115-39.

International Food Policy Research Institute (IFPRI) (2012), Global Hunger Index: The Challenge of Hunger: Ensuring Sustainable Food Security Under Land, Water, and energy Stress', Washington, DC, US: International Food Policy Research Institute. 
International Fund for Agricultural Development (IFAD) (2013), 'IFAD President's statement on impacts of investment on African agriculture and the principals for responsible agricultural investment (PRAI)’, Yokohama, Japan, 2 June.

Lee-Smith, D. (2010), 'Cities feeding people: an update on urban agriculture in equatorial Africa', Environment and Urbanization, 22, 483-99.

Levasseur, P. (2019), 'Can social programs break the vicious cycle between poverty and obesity? Evidence from urban Mexico’, World Development, 113, 143-56.

M.S. Swaminathan Research Foundation (MSSRF) and World Food Programme (WFP) (2010), The State of Food Insecurity in Urban India, Chennai, IN: M.S. Swaminathan Research Foundation and World Food Programme.

Maxwell, D. (1999), 'The political economy of urban food security in sub-Saharan Africa', World Development, 27, 1939-53.

Monteiro, C., W. Conde and B. Popkin (2007), 'Income-specific trends in obesity in Brazil: 19752003’, American Journal of Public Health, 97, 1808-12.

Popkin, B. (2017), 'Relationship between shifts in food system dynamics and acceleration of the global nutrition transition’, Nutrition Reviews, 75(2), 73-82.

Popkin, B. and P. Gordon-Larsen (2004), 'The nutrition transition: worldwide obesity dynamics and their determinants', International Journal of Obesity, 28, S2-S9.

Popkin, B., L. Afair and S. Ng (2012), 'Global nutrition transition and the pandemic of obesity in developing countries’, Nutrition Review, 70, 3-21.

Portes, A. and B. Roberts (2005), 'The free-market city: Latin American urbanization in the years of the Neoliberal Experiment', Studies in Comparative International Development, 40, 43-82.

Reardon, T. and C. Timmer (2012), 'The economics of the food system revolution', Annual Review of Resource Economics, 4, 225-64.

Roberts, B. (2005), 'Globalization and Latin American cities', International Journal of Urban and Regional Research, 29, 110-23.

Rodgers, D., J. Beall and R. Kanbur (2011), 'Latin American urban development into the twentyfirst century: towards a renewed perspective on the city', European Journal of Development Research, 23(4), 550-68.

Roemling, C. and M. Qaim (2013), 'Dual burden households and intra-household nutritional inequality in Indonesia', Economics \& Human Biology, 11, 563-73.

Rtveladze, K., T. Marsh, S. Barquera, L. Sanchez Romero, D. Levy, G. Melendez, L. Webber, F. Kilpi, K. McPherson and M. Brown (2013), 'Obesity prevalence in Mexico: impact on health and economic burden', Public Health Nutrition, 1, 1-7.

Ruel, M., J. Garrett, S. Yosef and M. Olivier (2017), 'Urbanization, food security and nutrition', in S. de Pee, D. Taren and M. Bloem (eds), Nutrition and Health in a Developing World, Part VII, New York, NY, US: Humana Press, pp. 705-35.

Satterthwaite, D., G. McGranahan and C. Tacoli (2010), 'Urbanization and its implications for food and farming', Philosophical Transactions of the Royal Society B, 365, 2809-20.

Saunders, D. (2010), Arrival City: The Final Migration and Our Next World, Toronto, ON, CA: Knopf Canada.

Seto, K., J. Golden, M. Alberti and B. Turner (2017), 'Sustainability in an urbanizing planet', Proceedings of the National Academy of Sciences, 114(34), 8935-38.

Sgro, J., B. Frayne and C. McCordic (2019), 'Linking the sustainable development goals through an investigation of urban household food security in Southern Africa’, Journal of Sustainability Research, 1(3), e190004.

Smith, D. (1998), 'Urban food systems and the poor in developing countries', Transactions of Institute of British Geographers, 23(2), 207-19.

Smith, D. (2019), Third World Cities in Global Perspective: The Political Economy of Uneven Urbanization, New York, NY, US: Routledge.

Spoor, M. and M. Robbins (eds) (2012), Agriculture, Food Security and Inclusive Growth, The Hague, NL: Institute of Social Studies.

Steel, C. (2008), Hungry City: How Food Shapes Our Lives, London, UK: Vintage.

Subramanian, S. and G. Davey Smith (2006), 'Patterns, distribution and determinants of under and over-nutrition: a population-based study of women in India', American Journal of Clinical Nutrition, 84, 633-40. 
Swindale, A. and P. Bilinsky (2006), 'Development of a universally applicable household food insecurity measurement tool: process, current status, and outstanding issues’, Journal of Nutrition, 136, 1449S-52S.

Tacoli, C. (2019), ‘The urbanization of food insecurity and malnutrition', Environment and Urbanization, 31(2).

Teng, P. and M. Escaler (2010), 'Food (in)security in urban populations', Working Paper No. 5, Asia Security Initiative Policy Series: RSIS Centre for Non-Traditional Security Studies, Singapore.

Teng, P., M. Escaler and M. Caballero-Anthony (2011), 'Urban food security: feeding tomorrow’s cities', Significance, 8, 57-60.

Thurlow, J., P. Dorosh and B. Davis (2019), 'Demographic change, agriculture, and rural poverty’, in C. Campanhola and S. Pandey (eds), Sustainable Food and Agriculture: An Integrated Approach, Section 1: Food and Agriculture at a Crossroads, Academic Press, Chapter 3, pp. 31-53.

Tuholske, C., K. Andam, J. Blekking, T. Evans and K. Caylor (2020), 'Comparing measures of urban food security in Accra, Ghana’, Food Security, accessed 3 March 2020 at https://doi. org/10.1007/s12571-020-01011-4.

United Nations (UN) (2015), World Urbanization Prospects: The 2014 Revision, New York, NY, US: UN Population Division.

United Nations (UN) (2017), The New Urban Agenda, Habitat III Secretariat, accessed 3 March 2020 at http://habitat3.org/wp-content/uploads/NUA-English.pdf.

United Nations (UN) (2018), The Sustainable Development Goals Report 2018, New York, NY, US: United Nations.

United Nations (UN) (2019), World Urbanization Prospects: the 2018 Revision, New York, NY, US: UN Population Division.

United Nations Department of Economic and Social Affairs (UNDESA) (2018), World Urbanization Prospects: The 2018 Revision, New York, NY, US: UNDESA Population Division.

United Nations Development Programme (UNDP) (2012), African Human Development Report 2012: Towards a Food Secure Future, New York, NY, US: UNDP.

Van Hook, J., C. Altman and K. Balistreri (2013), 'Global patterns in overweight among children and mothers in less developed countries', Public Health Nutrition, 16, 573-81.

Wiesmann, D., L. Bassett, T. Benson and J. Hoddinott (2009), Validation of the World Food Programme's Food Consumption Score and Alternative Indicators of Household Food Security, Washington, DC, US: International Food Policy Research Institute.

Zingel, W., M. Keck, B. Etzold and H. Bohle (2011), 'Urban food security and health status of the poor in Dhaka, Bangladesh’, in A. Krämer, M. Khan and F. Kraas (eds), Health in Megacities and Urban Areas, London, UK: Springer, pp. 301-19.

Ziraba, A., J. Fotso and R. Ochako (2009), 'Overweight and obesity in urban Africa: a problem of the rich or the poor?', BMC Public Health, 9, 465. 